\title{
Implementing Self Access Material for Promoting Learner Autonomy In Teaching ESP
}

\author{
Welly Kuswanto \\ University of Muhammadiyah Malang \\ (wellykuswanto@yahoo.com)
}

\begin{abstract}
This research used qualitative research design. Fraenkel and Wallen (2006) define qualitative research as documenting or portraying the everyday experience of individuals by observing and interviewing them. In this case, the researcher interviewed, observed teaching and learning ESP process and documentation by collecting document needed. Finally, Teacher as facilitator is easy to develop learners autonomy in teaching ESP by utilizing Self Access Material in form of providing relevant videos, providing software and online sources, producing inhouse material development, making authentic podcasts accessible, promoting CALL, turning workshop recordings into self-access activities and using authentic music resources. By fostering self access material and implement it by using nine strategies namely setting objectives, selection of materials, methods, teacher's role, teacher-learner relationship, learning environment, homework, presentation and talks and evaluation, teacher is able to trigger the learners to develop the ESP materials given.
\end{abstract}

Keywords: Learner autonomy, self access material, ESP.

"Fostering autonomy in language learners has now become an accepted part of language education as learner autonomy plays such a central role in the language learning process" (Benson, 2009). One way institutions might enhance opportunities for learners to develop autonomy is through self access material such as doing the task of English for Specific Purposes (ESP) material outside the class. Self Access Material can also be accessed in Self Access Center and Library which is provided by the institution or the university.

"Ideally self-access materials should be training learners to become less and less dependent on self-access materials and more capable of gaining from any exposure to the language in use that they experience. One way of doing this is to add a final activity to self- access materials which encourages the learners to seek extra authentic texts and to try to make discoveries from them" (Tomlinson, 2010). "Another way is to actually advise the learners how to become more independent" (Cooker \& Torpey, 2004). Through Self Access Material, the learners will learn independently while having a lot of tasks of ESP material given by teacher. In this case, the learners will be the learner autonomy.

The concept of learner autonomy has been central to the Council of Europe's thinking about language teaching and learning since 1979, when Henri Holec wrote Autonomy and foreign language learning (cited here as Holec 1981). Holec began by defining learner autonomy as the "ability to take charge of one's own learning", noting that this ability " is not 
inborn but must be acquired either by natural means or (almost often happens) by formal learning, i.e. in a systematic, deliberate way", and pointing out that "To take charge of one 's learning is to have [...] the responsibility for all the decisions concerning all aspects of this learning [...]" (Holec 1981, p. 3).

Holec's report was a contribution to the Council of Europe's work in adult education, which sought to promote the learner's freedom" by developing those abilities which will enable him to act more responsibly in running the affairs of the society in which he lives" (ibid., p. 1). When learner autonomy is one of its defining goals, adult education becomes an instrument for arousing an increasing sense of awareness and liberation in man, and, in some cases, an instrument for changing the environment itself. From the idea of man "product of his society", one moves to the idea of man " producer of his society" (Janne 1977, p. 3; cit. Holec 1981, p. 1)

Learner autonomy, in other words, belongs together with the idea that one of the functions of (adult) education is to equip learners to play an active role in participatory democracy. That is why it remains central to the Council of Europe's educational concerns.

According to a large body of empirical research in social psychology, autonomy - " feeling free and volitional in one's actions" (Deci 1995, p. 2) - is a basic human need. It is nourished by, and in tum nourishes, our intrinsic motivation, our proactive interest in the world around us. This explains how learner autonomy solves the problem of learner motivation: Autonomous learners draw on their intrinsic motivation when they accept responsibility for their own learning and commit themselves to develop the skills of reflective self-management in learning; and success in learning strengthens their intrinsic motivation. Precisely because autonomous learners are motivated and reflective learners, their learning is efficient and effective (conversely, all learning is likely to succeed to the extent that the learner is autonomous). And the efficiency and effectiveness of the autonomous learner means that the knowledge and skills acquired in the classroom can be applied to situations that arise outside the classroom when doing the tasks of ESP material.

The major problem seems to be that emphasis is put in the first place on setting up teaching and learning process on certain material to foster learners' autonomy in doing some tasks. Most the learners in ESP Class are not mastering in English Language Skills, namely reading, listening, speaking and writing. ESP as one of the courses which is provided by the department tends to solve these lacks of learners' competences. There is the need, therefore, to research on how language teaching and learning can be restructured in order to foster independent learning inside and outside the class by providing self access material.

Self access material mostly in Self Access Centre and Library. Most of the materials in self-access centers can be classified in different ways. "They may be authentic, didactic, published language learning materials, and/or adapted and designed materials that fit the students' needs in each setting" (Gardner \& Miller, 1999). Materials as the core of some self- access centers or libraries as vital role to support learners to be autonomy. The learners use materials in order to engage in language learning activities such as reading books, playing board games, answering exercises, listening to recordings and utilizing CALL to develop their understanding about language skills.

Sturtridge (1997), states that learners' acceptance or rejection of these centers might be heavily influenced by the quality of the materials. When acquiring, designing and adapting materials, it is necessary that these materials enable learners to use them independently, without the direct control of the teacher (Tomlinson, 1998). Several authors (Dickinson, 1987; Sheering, 1989; Tomlinson, 1998) have suggested the features materials 
should have. Importantly, Reinders and Lewis (2006) identified a set of specific features to evaluate self-access materials to allow more effective practices at self-access centers. To determine those features, first they reviewed the work cited above among others. Then they applied a questionnaire as proposed by Gardner and Miller (1999) to gather data about what the students at the SAC thought was good material for self-access. Ultimately, they created a checklist to evaluate materials that focused on the selection, the access, the learning process and learning to learn features.

Self Access Material commonly used by learners to broaden their understanding after getting ESP material. The learners should have Self Access Material such as in house material development, authentic podcasts accessible, CALL, Turning Workshop Recordings Into Self-Access Activities and Using Authentic Music Resources by utilizing online internet access. For leaners, indirectly, they trigger their intrinsic motivation when they accept responsibility to do ESP material outside the class to develop their language skills in learning ESP.

This paper, therefore, presents a model for promoting learner autonomy using selfaccess material in teaching ESP. This model is based on the different tasks that are to be accomplished for such a system to work efficiently. For this purpose, a description of the jobs that would ideally constitute a self-access center is provided. This does not mean, however, that only institutions with such a complete staff can set up a self-access material. Every institution - according to its nature, needs and constrains - should consider how the tasks discussed in form of learning autonomy, and decide whether teacher and self access material are necessary for that purpose.

\section{Method}

The researcher classifies the research method into research design, site and participants, data collection techniques, data analysis, data validity and concluding remarks.
This study aimed at describing the implementation of Self Access Material for Promoting Learner Autonomy in teaching ESP (The study of International Class Program at Sharia Business Law Department, Sharia Faculty, State Islamic University Maulana Malik Ibrahim Malang).

In accordance with the aims of this study stated earlier, descriptive qualitative study was chosen since it was suitable to give a complete description of the implementation of Promoting Learner Autonomy in Teaching ESP. As stated by Creswell (2008, p. 254) that descriptive qualitative study aims at investigating detail rendering of people, places, or events in a setting in qualitative approach. Besides, Wu and Volker (2009) also state that descriptive qualitative design is used to give a description and explanation of beliefs, meanings in context-specific setting and behaviors.

This research was conducted in the International Class Program of Sharia Business Law, Sharia Faculty, State Islamic University, Maulana Malik Ibrahim of Malang. The reason of choosing this level and university as the site of this research was because not only the learners of regular class are not mastering in language skills but also the learners of international class program. The main participant (the focus) of this research was the Learners and English teacher in teaching and learning in English for Specific Purposes.

Data collection techniques employed in this study were classroom observation, interview and document analysis. As stated by Creswell (2007) the data collection in descriptive study is typically extensive, drawing on multiple sources of information, such as observation, interview, and documentation by getting the syllabus and lesson plan given by the ESP lecturer.

After collecting the data through classroom observation and interview, those data were then analyzed by descriptive qualitative data analysis. The data analysis was divided into two steps; data analysis of classroom observation and data analysis of 
the interview. In analyzing and presenting the analysis of each research instrument, this study proposed descriptive explanation.

The data gained from three instruments were then cross checked by using triangulation. Triangulation can help the researcher to find the conclusion of the results among different research instruments (Alwasilah, 2000 and Frankael \& Wallen, 1990). The data taken from three different instruments then were compared in order to avoid unclear answers from the participant that probably emerged.

\section{Result and Discussion}

Implementing Self Access Material for Promoting Learner Autonomy in teaching ESP can be applied by first, utilizing self access material in form of Self Access Learning Center (SALC), In House Material Development, Making authentic podcasts accessible, Promoting Call, Photography Wall, Promoting SALC Materials And Services, Turning Workshop Recordings Into Self-Access Activities and Using Authentic Music Resources. And second, self access material is implemented into nine strategies such as setting objectives, selection of materials, methods, teacher's role, teacher-learner relationship, learning environment, homework, presentation and talks and evaluation.

\section{Self-Access Learning Center (SALC)}

The context The Self-Access Learning Centre (SALC) or called by the library of the International Class Program of Sharia Business Law Department, Sharia Faculty, Maulana Malik Ibrahim State Islamic University of Malang is an English-environment intended to provide opportunities to develop language skills and also to facilitate the development of learner autonomy. The SALC contains over 1,000 materials such as books, DVDs, CDs, magazines, and computer-based activities. It also provides equipment, facilities and services to facilitate language study and practice such as multi-purpose rooms, audio-visual equipment, computers, and an advisory services.

The SALC also runs activities such as workshops, competitions, and events. All of these are enabled by a team of administrative staff, professional learning advisors, and

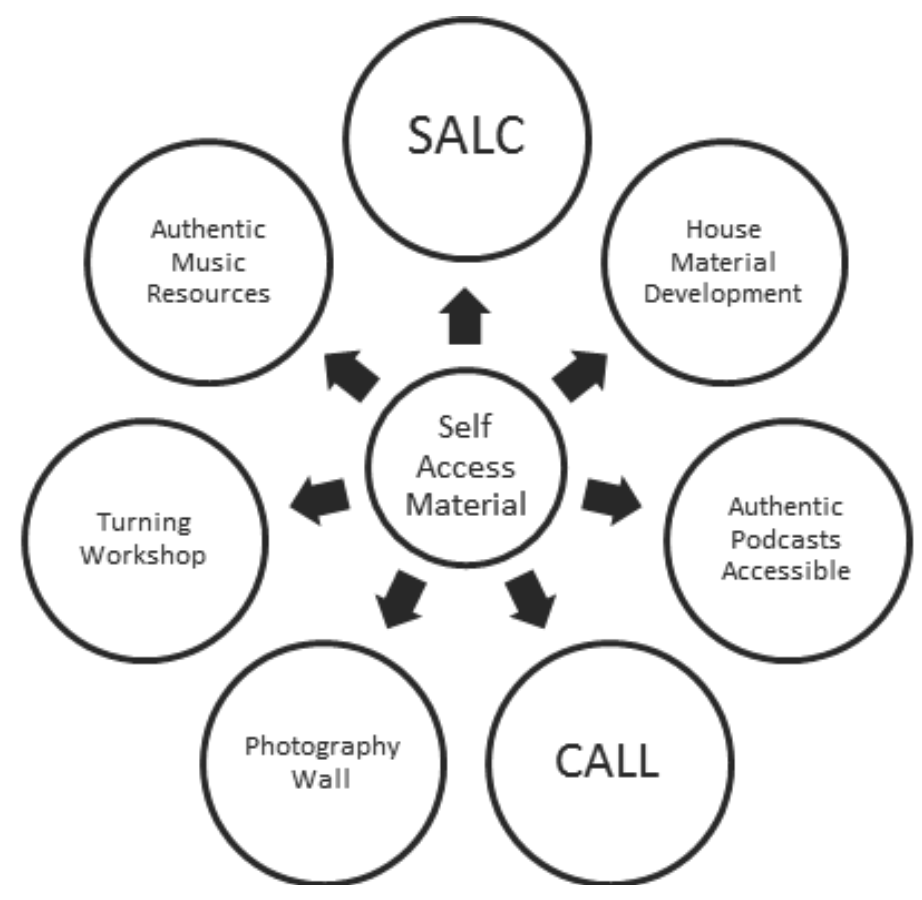

Figure 1. Parts of Self Access Material in Teaching ESP 
student employees. The philosophy of the centre is that learning should be fun and enjoyable, the use of the SALC should be optional and voluntary, and the atmosphere should be warm and inviting (Cooker, 2007). The definition of learner autonomy that the SALC favors is one that emphasizes cooperation with other learners: "Learner autonomy is characterized by a readiness to take charge of one's own learning in the service of one's needs and purposes. This entails a capacity and willingness to act independently and in cooperation with others, as a socially responsible person" (Dam, Eriksson, Little, Miliander, \& Trebbi, 1990, p. 102). As Benson (2001) points out, there is not necessarily a relationship between the provision of a self-access centre and the development of learner autonomy.

\section{In-House Materials Development}

"Self-access materials produced inhouse have a number of benefits for language learners" (Tomlinson, 1998). Firstly, the materials can be tailored to suit the needs, level, and interests of the target users. Secondly, they can be designed especially for self-access use and can include appropriate instructions, scaffolding, hypothesis testing, and awarenessraising activities. Finally, they can refer and link to other self-access materials in order to further support and guide learners. Tomlinson (2003) points out that materials (designed for both general and self-access use) should be relevant, engaging, visually appealing, achievable, piloted, and proofread. The learners of Islamic law department are offered to do the task based on self access materials online and the learners are able to do in their house. The reason for giving this task is to make autonomous learners enjoyable and fun.

\section{Making Authentic Podcasts Accessible}

Authentic texts are materials which were originally intended for native speakers and were not designed for language learning purposes (McGarry, 1995). Nevertheless, there are a number of benefits of using authentic texts for language learning, for example, they provide access to the target language community and to help learners see the language they are studying in a context outside the classroom. Secondly, the texts can be very motivating as the learners are aware that the texts have been written for native speakers (Little, Devitt, \& Singleton, 1988). Thirdly, exposing learners to non graded, unedited texts from time to time can be beneficial to help them learn to deal with ambiguity or uncertainty (Benson, 2001). However, authentic texts can be challenging for a learner and need to be carefully selected and possibly scaffolded so that learners do not become too frustrated or demotivated. The materials created in this project combined the desire to use authentic materials as self-access listening resources with the recent popularity of podcasts and $\mathrm{mp} 3$ players. The materials are based on authentic travel podcasts, as travel generally proves to be a popular theme among learners.

The lessons are designed to enable the learners of the International Class Program of The Sharia Business Law Department, Sharia Faculty, Maulana Malik Ibrahim State Islamic University of Malang to utilise podcasts for listening practice, pronunciation practice and simply learning new words and phrases. The lessons are available in the Listening and CALL (computer assisted language learning) sections of the SALC. In addition, mp3 players are available at the SALC counter for students to listen to the podcasts.

The podcasts used in this series of lessons are generally around 15 minutes in length. However, the students are not expected to listen to the whole podcast. The lesson is divided into six parts, each containing a short extract from the podcast. The total listening time is therefore approximately 8 minutes, and the students are advised to complete as much or as little as they want at any given time. There is a general introduction to each lesson designed to get the students thinking about the location of the travel podcast. Following this, each individual part of the 
lesson begins with a summary of what the listener will hear in the particular extract and attempts to activate schemata by asking students to imagine themselves in a similar situation or think about a time they have had a similar experience. This is followed by a short vocabulary section, including example sentences, to scaffold certain vocabulary items. Finally, the students listen to the appropriate segment of the podcast and attempt a number of comprehension questions.

There is a full answer sheet provided at the end of the whole lesson. In addition, the podcasts are also fully transcribed so subsequent to listening and attempting the questions, the students are encouraged to listen repeatedly with the aid of the transcripts. Furthermore, the transcript for each part of the lesson also includes extra information to explain any interesting culturally specific points the students may not be aware of.

\section{Promoting CALL}

Two SALC CALL materials development projects currently underway at KUIS are an online writing web resources page and communicative exercises utilizing Skype. The writing web page gives students access to online resources to help them in any area of writing that interests them. It provides students with information about assistance with writing they can receive in the SALC, such as through the Writing Centre, with links to videos explaining the sign up and teacher consultation process. Students can also click through to online student forums where they can discuss and share their writing with their peers. In addition to directing students to online and real world materials within the SALC, students are presented with a range of online writing resources suitable for any English level, from how to use grammar to guidance on writing essays. The website seeks not only to promote student use of the SALC and its resources, but by making both in-house and external materials available in the one location it is seeking to give students greater control over their study options.

The Skype student exercises seek to build learner confidence in telephone style conversation through structured scenarios they may face in real life. While learners are given guidance for their conversations, they are encouraged, through the task design, to create an original conversation and not merely mimic example texts. During the trial stage learners responded positively to the exercises, finding them beneficial and many expressing a desire to use these exercises in the SALC. The dialogues that arose proved to be varied with learners taking control of the conversations and often expanding them beyond the activity parameters. In addition to the language goals of the exercises, learners are gaining valuable experience in using emerging technologies and increasing their computer literacy skills in English.

\section{Photography Wall}

The SALC has a large array of selfaccess resources available for learners to use based on their own needs and interests. There was a desire to create a fun interactive activity whereby the learners themselves could be involved in the process rather than just using the final product; the end result being some -thing which also added a visual impact to the SALC. With this in mind, the SALC Photography Contest was created. Learners were able to submit a photograph based on a set theme, along with a paragraph about the photograph. The photograph was submitted in JPG format and the paragraph was limited to 150 words.

\section{Promoting SALC Materials and Services}

As mentioned in the introduction, the SALC has a wide range of resources available for the learners to use. With so much on offer, it is easy to imagine that a student new to the SALC may feel overwhelmed by the many choices. Learners may not always have a clear idea themselves of what they want or need. They may not know what is best for their own language learning - most language 
learners do not (Nunan, 1997). Furthermore, the resources the learners actually see and recognize in the SALC are just a fraction of what is really available. And finally, even if they do know a particular resource exists, they may not be familiar with it and may not know how to make the most effective and efficient use of it. We cannot and do not expect our learners to jump headfirst into the world of self-access without any guidance or support.

Benson (2001) reminds us that "fostering autonomy does not imply that we simply leave learners to their own devices, but that we actively encourage and assist them" (p. 75). One way in which we attempt to assist learners in their use of the SALC is to provide pathways into the resources and to provide scaffolding for the self-access process. Learners are informed of what is available and given suggestions or advice on how best to adapt those resources to their own learning styles, needs, and preferences. Dissemination of this information is done through a variety of means: newsletters, signs and posters around campus, a bulletin board, leaflets that are both made available for learners to take freely and also handed out in classes, the SALC student website, announcements through e-mail, a SALC orientation tour or lesson for all new learners, advice and suggestions provided by teachers in their classes, and finally, the learning help desk.

This year, several members of the selfaccess materials development team have been working to create yet another way in which we attempt to provide those pathways into the system and the guidance that learners need. In production now is a video which provides learners with information about the mentioned resources that are available in the SALC.

This video takes its inspiration from the video monitors on some trains in some countries such as Australia and Tokyo. The videos seen on the train provide a constant stream of information to a captive audience that can watch the video for a short time and leave, then come back and view a separate segment of the video at a later time. Following this example, the video being created at KUIS is intended to be shown on a continuous loop at places around campus where learners often congregate, such as group study areas in the

SALC, the student cafeteria, and in the halls between classes. The video is quite simple: a series of basic PowerPoint type slides with information about the various materials, facilities, activities, and people in the SALC; pictures of these resources; and maps of the SALC to guide the learners to these resources. The video also includes excerpts of interviews with teachers, SALC staff members, student workers, and SALC users giving recommendations and advice, as well as sharing their own experiences. The interviews have been edited extensively to remove the stops and starts, retakes, and unclear responses typical of unrehearsed interviews in order to present the information in as clear and quick a manner as possible. In addition, the interviewer's questions have been replaced with slides displaying the interviewer's comments and questions in writing. This is followed by a movie clip with audio of the interviewee's edited response to the question. This allows for a great amount of freedom in the video design, creation, and editing process. The order of questions and responses can be changed, and separate responses.

From a number of interviews to one particular question can be shown one after the other. Finally, to allow for the possibility of noaudio, muted showing, abbreviated subtitles that are timed according to the interviewee's responses are included. The video may succeed in reaching a part of the student population that the other methods we employ for the dissemination of information about SALC resources may have missed. We believe it will be attractive to learners and in tune with the modes of communication they are most used to. Given this information, our learners will hopefully feel less daunted by self-access materials and will eventually discover what works best for them. 


\section{Turning Workshop Recordings Into Self-Access} Activities

Self-access learning workshops are regularly offered in the SALC. Given by English teachers and learning advisors, these workshops invite learners to explore topics related to popular activities and materials in the SALC, such as "How to watch movies" or "How to improve TOEIC scores". All workshops are open to the entire campus, and they often fill to capacity with interested learners. Filming the workshops could offer a range of benefits. For instance, compared with other forms of material designed for the SALC, these workshop DVDs require relatively little extra effort to make, since the workshops are already in place. In addition, these DVDs increase the degree to which the material is made self-accessible, as the learners can choose to "attend" the workshop any time they wish (and this is best facilitated if the workshop handout is adapted for DVD viewing as well).

\section{Using Authentic Music Resources}

This final project also capitalizes on the intrinsic interest of authentic texts; this time the authentic texts take the form of music. In an effort to maximize the utility of the SALC's collection of English music CDs to support learners' autonomous learning, song worksheets are being created. Since these song worksheets have the potential to draw on learners' intrinsic enjoyment in listening to specific songs to provide opportunities to develop their English, it is important to create worksheets for songs that the learners are interested in. Therefore, it is beneficial to conduct a survey to find out which songs and artists are popular among the current student population to help guide decisions of song selection for the worksheets. At KUIS, learners in the SALC were surveyed since learners who already visit the SALC are more likely to be the ones to use the song worksheets.

When creating the actual tasks for a song worksheet, particular care must be given to the format and type of tasks in order to adhere to copyright restrictions. Since the song worksheets will be used outside of the classroom, Japanese copyright law prohibits the reproduction of a song's lyrics and it prohibits providing an Internet link to a web-page containing the lyrics. As such, close activities (i.e., gap fills) cannot be used. However, one method that can be used to overcome these restrictions is to create a pre-listening vocabulary exercise followed by a post-listening comprehension task. For example, a pre-listening exercise can have learners match key words, phrases, and idioms used in the song to their correct meanings. Once learners have completed the exercise, they should be able to compare their answers to an answer key on the back of the worksheet. Learners can then be instructed to listen to the song and try to answer the comprehension questions in the post-listening section. A more communicative post-listening task can have learners discuss the meaning of the song with a friend. Furthermore, different types of songs can be used to focus on different aspects of language. For instance, songs that have a lot of reduced speech, such as bringin', gonna, and 'cuz, can be used to raise learners' awareness of the difference between spoken and written English. A pre-listening task focusing on reduced speech can list the reduced forms of the words or phrases (wanna, goin', hafta) and have learners write down the written forms (want to, going, have to).

\section{Teacher Position in Implementing Self Access Material in Teaching ESP}

After implementing self access material to guide learners in broadening their understanding in ESP material, teacher need some techniques as follow-up of self access material to promote leaner autonomy by using nine strategies, namely setting objectives, selection of materials, methods, teacher's role, teacher-learner relationship, learning 
environment, homework, presentation and talks, and evaluation.

In promoting autonomous learners in teaching ESP, teacher position implements all materials in ESP facilitated by Self Access Material and using nine strategies which have been written by Jeremy Harmer (2003, p. 335), Scott Thornburry (2005, p. 89) and Holec $(1979$, p. 10$)$. The nine strategies are setting learners expectation and the materials may in form of newspapers, magazines, videos and others self access materials in the library of self access center. Third is methods, the methods used in teaching ESP by giving task and group discussion for learners. And the discussion may be take place in the library or self access center to utilize self access material, task and group discussion will promote

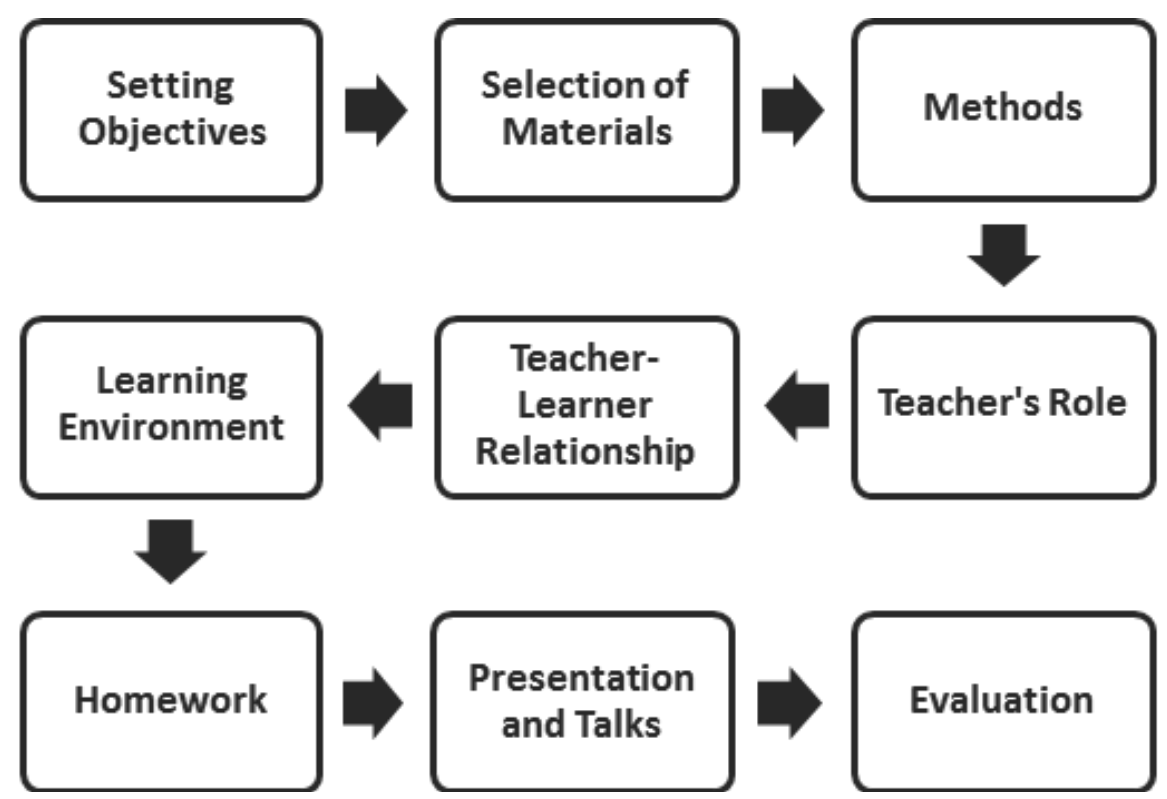

Figure 2. The Nine Strategies to Promote Autonomous Learners in Teaching ESP

objectives, selection of materials, methods, teacher's role, teacher-learner relationship, learning environment, homework, presentation and talks, and evaluation.

Some steps in implementing nine strategies of teaching ESP as follows: First is setting objectives, in this step, teacher designs the objective of teaching ESP through the syllabus. By using the syllabus, teacher will know in depth the process in teaching ESP covers basic competence, core competence material, evaluation, time allotment, and references (Permendikbud, 2013, p. 93). Second is selection of materials, after teacher sets the objectives of teaching ESP, teacher selects the available material for teaching ESP. Material of teaching ESP must be based on teacher and autonomous learners. Fourth is Teacher's role, the available teachers role when teaching ESP are teacher as prompter, resource and tutor (Jeremy Harmer, 2003, p. 72). Fifth is teacher-learner relationship, When teaching ESP, teacher gives the task for learners in form of groups to promote autonomous learning, direct and indirectly, learners have participated in teaching and learning process. The effect, teacher and learners having relationship through teaching and learning process.

Sixth is learning environment, when teaching ESP direct and indirectly acquaints learners to learn from the Environment and utilize in house materials development as a part of self access material. The environment gives a wider lessons for learners in terms 
of how to be a member in society and how to interact with others. When learners learn from the environment, directly and indirectly, learners recognize how to express emotions appropriately in accordance with the demands of their social environment. Seventh is Homework, After explaining ESP material, homework is available to promote autonomous learning. Homework is one of teacher instructions to promote autonomous learners in teaching ESP. In order to be maximum for giving learners homework, teacher need to discuss with learners how much homework they can cope with, given the other commitments they have. Eight is Presentation and talks, After finishing student's homework of ESP material, the learners are offered to give presentation and talks in front of other learners. Mostly, presentation and talks of ESP material are in terms of academic presentation. Academic presentations refers to the learners who are studying English for Academic Purposes (EAP) are likely to need preparation in giving academic presentations or conference papers (Scott Thornbury, 2005, p. 94). Ninth is Evaluation. Evaluation is the last strategies of teaching ESP. In promoting autonomous learners, evaluation is needed for teacher in terms of giving feedback for learners' mistake when learning ESP. Teacher or educator serves as a benchmark for evaluating whether or not the teacher was successful in providing teaching ESP. Teaching can be said to be successful if visible changes or changes in learners' behavior toward better.

\section{Conclusion}

One of solutions to promote learning autonomy by Implementing Self Access Material as facilities to trigger and support learners by giving ESP material in SALC, doing the task of ESP material by using in-House Material Development, Making authentic podcasts accessible, Promoting Call, Photography Wall, Promoting SALC Materials And Services, Turning Workshop Recordings
Into Self-Access Activities, Using Authentic Music Resources. These kinds of self access material will be effectively implemented by using nine strategies namely setting objectives, selection of materials, methods, teacher's role, teacher-learner relationship, learning environment, homework, presentation and talks, and evaluation. After implementing self access material and nine strategies, the learners draw on their intrinsic motivation when they accept responsibility for their own learning and commit themselves to develop the skills of reflective self-management in learning.

This research is recommended for teachers who are teaching ESP by using self access material and nine strategies as the techniques for promoting autonomous learners inside and outside the class. By applying self access material and the nine strategies as mentioned in finding and discussion, ESP teacher will be on the right position as facilitator to foster leaners autonomy.

\section{References}

Benson, P. (2001). Teaching and researching autonomy in language learning. Harlow: Longman/Pearson Education.

Benson, P. (2009). Making sense of autonomy in language learning. In R. Pemberton, S. Toogood, \& A. Barfield (Eds.), Maintaining control: Autonomy and language learning (pp. 13-26). Hong Kong University Press.

Cooker, L. (2007). The Self-Access Learning Centre at Kanda University of International Studies (KUIS), Chiba, Japan. Independence, 41, 29-32.

Council of Europe, (2000/2004): European Language Portfolio (ELP).' Principles and Guidelines. With added explanation notes. Strasbourg: Council of Europe. (DGIV/EDU/LANG (2000) 33 rev.1)

Council of Europe, (2001): Common European Framework ofReferencefor Languages.. 
Learning, teaching, assessment. Cambridge: Cambridge University Press.

Creswell, W. John. (2007). Qualitative Inquq and Research Design (choosing amongive approaches) second edition. California: Sage publication, Inc.

Dam, L., Eriksson, R., Little, D., Miliander, J., \& Trebbi, T. (1990). Towards a definition of autonomy. In T. Trebbi (Ed.), Third Nordic workshop on developing autonomous learning in the FL classroom. University of Bergen. Retrieved May 1, 2009, from http://www.warwick.ac.uk/ go/dahla/archive/trebbi_1990.

Deci, E. (with R Flaste), (1995): Why we do what we do: understanding self-motivation. New York: Penguin.

Dickinson, L. (1987). Self-Instruction in Language Learning. Cambridge, UK: Cambridge University Press.

Fraenkel, J.R. , \& Wallen, N.E. (2006): How to design and evaluate research in education, New York: McGraw - Hill.

Gardner, D., \& Miller, L. (1999). Establishing self-access. Cambridge, UK: Cambridge University Press.

Jonassen, D. H. (1996). Computers in the classroom: Mindtools for critical thinking. Englewood Cliffs, NJ: Merrill.

Harmer, Jeremy. (2003). The Practice of English Language Teaching. Longman.

Holec, H., (1981): Autonomy and foreign language learning. Oxford: Pergamon. (First published 1979, Strasbourg: Council of Europe)

Jonassen, D., Peck, K., \& Wilson, B. (1999). Learning with technology: A constructivist perspective. Upper Saddle River, NJ: Prentice Hall.

Lajoie, S. P. (2005). Cognitive tools for the mind: The promises of technology Cognitive amplifiers or bionic prosthetics? In R. J. Sternberg \& D. D. Priess (Eds.),
Intelligence and technology: The impact of tools on the nature and development of human abilities. (pp. 87-102) Mahwah, NJ: Lawrence Erlbaum.

Little, D., Devitt, S., \& Singleton, D. (1988). Authentic texts in foreign language teaching: Theory and practice. Dublin: Authentik. McGarry, D. (1995). Learner autonomy 4: The role of authentic texts. Dublin: Authentik.

Nunan, D. (1997). Designing and adapting materials to encourage learner autonomy. In P. Benson \& P. Voller (Eds.), Autonomy and independence in language learning (pp. 192-203). Harlow: Addison Wesley Longman Limited.

Strevens, P. (1988). ESP After Twenty Years: A Re-appraisal. In M. Tickoo (Ed.), ESP: State of the art (1-13). SEAMEO Regional Language Centre.

Sturtridge, G. (1997). Teaching and Learning in Self-Access Centres: Changing Roles. In P. Benson \& P. Voller (Eds.), Autonomy and independence in language learning (pp. 66-78). Harlow, UK: Longman.

Thornburry, Scott. (2005). How to Teach Speaking, Logman: University Press

Tomlinson, B. (1998). Materials development in language teaching. Cambridge: Cambridge University Press.

Wena, Made. (2011). Contemporary Innovative Learning Strategies, A Conceptual Overview of Operation. Jakarta : Bumi Aksara

Wu, Hung-Lan \& Volker, Deborah. (2009). The Use of Theory in Qualitative Approaches to Research: Application in End-ofLife Studies. A Journal of Advance Nursing, Volume 65, 2719-2732. Doi: 10.1111〉j.1365-2648.2009.05157.x 
